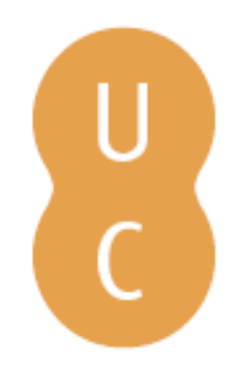

\title{
nombalina
}

\section{Política externa: modelos, actores e dinâmicas}

Autor(es): $\quad$ Freire, Maria Raquel; Vinha, Luís da

Publicado por: Imprensa da Universidade de Coimbra

URL

persistente:

URI:http://hdl.handle.net/10316.2/31197

DOI:

DOl:http://dx.doi.org/10.14195/978-989-26-0086-4_1

Accessed : $\quad$ 19-May-2017 17:27:33

A navegação consulta e descarregamento dos títulos inseridos nas Bibliotecas Digitais UC Digitalis, UC Pombalina e UC Impactum, pressupõem a aceitação plena e sem reservas dos Termos e Condições de Uso destas Bibliotecas Digitais, disponíveis em https://digitalis.uc.pt/pt-pt/termos.

Conforme exposto nos referidos Termos e Condições de Uso, o descarregamento de títulos de acesso restrito requer uma licença válida de autorização devendo o utilizador aceder ao(s) documento(s) a partir de um endereço de IP da instituição detentora da supramencionada licença.

Ao utilizador é apenas permitido o descarregamento para uso pessoal, pelo que o emprego do(s) título(s) descarregado(s) para outro fim, designadamente comercial, carece de autorização do respetivo autor ou editor da obra.

Na medida em que todas as obras da UC Digitalis se encontram protegidas pelo Código do Direito de Autor e Direitos Conexos e demais legislação aplicável, toda a cópia, parcial ou total, deste documento, nos casos em que é legalmente admitida, deverá conter ou fazer-se acompanhar por este aviso. 
Política Externa As Relações Internacionais em Mudança

$\frac{\mathrm{I}}{\mathrm{U}}$ 
Maria Raquel Freire

e Luís da Vinha

\section{CAPÍTULO 1}

\section{POLÍTICA EXTERNA: MODELOS, ACTORES E DINÂMICAS}

A política externa, tradicionalmente associada aos Estados, mas crescentemente associada a outros actores, como a União Europeia (UE), projecta interesses e objectivos domésticos/internos para o exterior. É assim entendida como uma ferramenta essencial no posicionamento dos actores no sistema internacional. No entanto, o desenho, formulação e implementação da política externa não é um processo simplista e linear, como analisado nos diferentes modelos teóricos e na necessidade de conjugação destes para um entendimento mais compreensivo do processo; e não tem lugar de forma isolada, revelando o carácter co-constitutivo das dimensões interna (doméstica) e externa (internacional) que acompanham todo o processo. A discussão agente/estrutura é, neste quadro, um referencial fundamental com alguma discordância relativamente à prevalência do agente sobre a estrutura ou, ao invés, da condicionalidade que a estrutura impõe ao agente. Neste contexto, a proposta avançada por James Rosenau (1966, 1969) de que a política externa implica uma relação bi-direccional entre as dimensões interna e externa, ultrapassando a convicção tradicional de que a política externa é dirigida por factores internacionais, foi generalizada nos estudos nesta área. Contudo, a discussão mantém-se relativamente ao peso relativo de cada uma destas dimensões no processo de formulação da política externa. Por um lado, há autores que argumentam que o contexto interno constitui a variável relevante na definição e prioritização da agenda de política externa (Neack et al., 1995; Saideman e Ayres, 2007: 191); por outro, 
as abordagens estruturalistas focam no papel da estrutura como informando os desenvolvimentos internos, e desse modo constituindo o elemento de referência fundamental (Keohane e Nye, 2000; Waltz, 1979).

Para além da tradução do debate agente/estrutura na teorização sobre política externa, outras dimensões de análise têm sido incorporadas em alguns estudos, nomeadamente questões mais subjectivas, mas não menos relevantes, como atitudes, crenças, valores e interesses subjacentes aos processos de formulação e decisão, e que têm contribuído essencialmente para a análise das motivações implicadas nos processos de política externa. Este debate implica a discussão do papel e características individuais do decisor, bem como a consideração dos quadros ideológicos em que as decisões são tomadas (Carlsnaes, 2003; Houghton, 2007; Jørgensen, 2006; Snyder et al., 1954). Como expressão deste desenvolvimento, estudos recentes introduziram novas metodologias na análise de política externa, como análise de discurso, estudando a linguagem da política externa (Campbell, 1993; Doty, 1997; Larsen, 1997; Sjöstedt, 2007). A análise de política externa tornou-se, assim, uma área de estudo complexa implicando múltiplas variáveis relativamente aos níveis de análise, actores, processos e resultados.

Este capítulo avança com algumas definições de política externa, apresenta os modelos teóricos de formulação e decisão em política externa, e explicita diferentes variáveis que devem ser tidas em conta em análises de política externa. Não pretendendo ser exaustivo, procura mapear as bases teóricas essenciais associadas à política externa, fornecendo os enquadramentos para uma análise mais detalhada e compreensiva de políticas externas diferenciadas.

\section{As origens da análise de política externa}

A análise de política externa enquanto abordagem teórica distinta teve a sua origem no período a seguir à Segunda Guerra Mundial. Segundo Hudson e Vore (1995) três trabalhos distintos estão na génese desta abordagem: Foreign Policy Decision-Making de Richard Snyder, Henry Bruck e Burton Sapin (1954); Man-Milieu Relationship Hypothesis in the Context of 
International Politics de Harold e Margaret Sprout (1956 e desenvolvido mais detalhadamente em 1965 no livro The Ecological Perspective on Human Affairs: With Special Reference to International Politics); e Pre-theories and Theories of Foreign Policy de James Rosenau (1966).

O estudo de Snyder, Bruck e Sapin foi inovador e importante, pois identificou o decisor humano como o principal determinante do comportamento do Estado. Desta forma, o foco da análise centrou-se no decisor e no seu entendimento da situação. Mais concretamente, "O objectivo analítico principal é a recriação do 'mundo' dos decisores conforme eles o vêem” (Snyder, Bruck e Sapin, 2002: 59). Igualmente significativo, o trabalho de Herman e Margaret Sprout foi fundamental para determinar a relação entre o psycho-milieu (o meio percepcionado pelos decisores e ao qual reage) e o operational milieu (o meio no qual as decisões são executadas). Relativamente à formulação e ao conteúdo das decisões políticas, o que importa é a forma como os decisores imaginam que o meio é, e não a forma como realmente é. Relativamente aos resultados operacionais das decisões, o que importa é como as coisas são, e não a forma como os decisores imaginam que são (Sprout e Sprout, 1957: 327-328). Por sua vez, o artigo de Rosenau, reforçando a necessidade de aplicar conhecimentos de outras ciências sociais nas explicações de política externa, contribuiu para uma análise multi-nível e multi-causal da complexidade associada à compreensão da mesma.

Embora os estudos de política externa tenham desenvolvido diferentes abordagens, os trabalhos acima referidos estabeleceram os pressupostos teóricos basilares da disciplina (Hudson e Vore, 1995), nomeadamente: o conhecimento das especificidades dos indivíduos envolvidos nas decisões de política externa é crucial para a compreensão das escolhas; a informação sobre estas especificidades deve ser incorporada na construção de teorias transnacionais e de médio-alcance; as teorias resultantes devem integrar múltiplos níveis de análise; e a compreensão do processo de formulação da política externa é tão importante, se não mais importante, do que a compreensão dos outputs da política externa.

Embora todos os trabalhos incorporassem estes pressupostos, cada um contribuiu de forma particular para o crescimento e consolidação de abordagens distintas na análise da política externa. Desta forma, o trabalho de 
Snyder, Bruck e Sapin catalisou os estudos dedicados à decisão de política externa, com especial enfoque nos processos de decisão e nas estruturas dos grupos responsáveis por essas mesmas decisões. Ao distinguir entre os diferentes milieu, os Sprout estiveram na génese dos trabalhos dedicados ao contexto da política externa, nomeadamente os que procuram compreender a dimensão cognitiva dos decisores (crenças, atitudes, valores, emoções, estilos, percepções). O enfoque teórico de Rosenau, por sua vez, estabeleceu os alicerces para os trabalhos de política externa comparada, com a sua ênfase na análise dos 'eventos' de política externa.

O sucesso destes diferentes trabalhos fez da análise de política externa uma componente central para a compreensão da política internacional. Porém, desde o fim da Guerra Fria os pressupostos subjacentes à análise de política externa adquiriram uma renovada importância e centralidade (Hagan, 2001). Devido à dificuldade das teorias tradicionais dominantes em explicar a complexidade da política contemporânea, o enfoque nos indivíduos e nos processos de decisão passou a assumir um lugar central na política internacional. Os novos desafios do pós-Guerra Fria cimentaram a convicção de que as teorias tinham de reconhecer que «com cada transformação sistémica... a vontade e imaginação humana são fundamentais ao influenciar a condução dos assuntos globais» (Hudson e Vore, 1995: 210). A natureza fluida do mundo pós-Guerra Fria amplificou a exigência de encontrar modelos capazes de lidar melhor com a complexidade da política internacional do que os modelos sistémicos tradicionais. De acordo com Hudson (2008), a análise de política externa contemporânea mantém os compromissos teóricos particulares que a demarcaram desde a sua concepção e que hoje se continuam a demonstrar relevantes para uma compreensão mais efectiva da complexidade da política internacional.

\section{Compreender a política externa}

Não existe uma definição absoluta e consensual de política externa, mas as várias definições avançadas contêm atributos e pressupostos semelhantes: 
«O sistema de actividades desenvolvido pelas comunidades para modificar o comportamento de outros Estados e para ajustar as suas próprias actividades ao ambiente internacional" (George Modelski apud Kegley e Wittkopf, 1995: 45);

"O esforço de uma sociedade nacional para controlar o seu ambiente externo pela preservação das situações favoráveis e a modificação das situações desfavoráveis» (James Rosenau apud Zorgbibe, 1990: 433);

"programa orientado para a resolução de objectivos ou de problemas elaborado pelos decisores políticos com autoridade (ou seus representantes), direccionado a entidades externas à jurisdição dos responsáveis pela formulação política» (Hermann, 1990: 5);

«O conjunto de objectivos, estratégias e instrumentos escolhidos pelos responsáveis governamentais pela formulação política para responder ao ambiente externo actual e futuro» (Rosati, 1994: 225).

Todas estas definições comungam de uma série de princípios e pressupostos, dos quais se destacam o papel dos governos estatais como actores privilegiados na formulação da política externa e a dimensão intencional da acção política. Nestas conceptualizações há dificuldade em compreender outros actores como agentes activos na política internacional, pois instituições não estatais não são consideradas. Assim, temos dificuldade em incluir entidades supra-estatais (como a ONU ou a UE) ou sub-estatais (como o Hezebollah e comunidades não-estatais) na análise da política internacional. Igualmente, estas definições não incluem os resultados não intencionais das decisões políticas, deixando uma lacuna conceptual por resolver. De facto, Kalevi Holsti (Gustavsson, 1999) já alertou para a distinção entre a política externa «intencional» e "actual», confirmando que os resultados das decisões políticas nem sempre são os inicialmente pretendidos. Por sua vez, Kjell Goldmann (Gustavsson, 1999) e Laura Neack (2008) têm salientado o facto de haver uma distinção a fazer entre a "política verbalizada" (acção que o actor declara que persegue) e a "política não-verbalizada" (acção de facto 
implementada). Vários autores defendem que as análises devem considerar a razão porque os actores declaram e seguem determinadas acções, pois a análise de política externa inclui o estudo dos processos, declarações e comportamentos (Neack, 2008: 10).

Tendo em consideração o exposto, este manual apresenta uma definição de política externa que procura ser o mais abrangente possível e que transponha algumas das lacunas conceptuais referidas. Assim, entende-se por política externa o conjunto de objectivos, estratégias e instrumentos que decisores dotados de autoridade escolhem e aplicam a entidades externas à sua jurisdição política, bem como os resultados não intencionais dessas mesmas acções.

Ao concentrar-se nos diferentes actores e nos diferentes processos e dinâmicas de decisão, a análise de política externa permite uma abordagem complementar que enriquece o nosso entendimento da política internacional. Mais concretamente, a análise de política externa centrada nos processos de decisão ajuda a "identificar padrões de decisão únicos e genéricos e gerar entendimentos sobre os estilos e personalidades de liderança que não podem ser revelados através de uma abordagem sistémica à política externa» (Mintz e DeRouen Jr., 2010: 5). Como referido, a política externa envolve dinâmicas complexas, como incerteza sobre o ambiente político, trade-offs diversos no momento da decisão, difusão da autoridade política, variabilidade nas estruturas de decisão (Hagan, 2001). Só uma abordagem assente na compreensão dos processos de decisão permite compreender estas complexidades. De facto, as teorias tradicionais das Relações Internacionais, sobretudo as teorias sistémicas, não explicam convenientemente muitos dos eventos da política internacional (Hagan, 2001), pois ao renunciar à análise dos processos de decisão e seus principais intervenientes, as teorias tradicionais acabam por não abordar factores fundamentais para uma compreensão mais completa dos acontecimentos internacionais, uma vez que qualquer Estado tem de decidir sobre uma agenda ampla que exige a tomada de decisões (Mintz e DeRouen Jr., 2010). Além do mais, a análise de política externa, ao focar nos diversos actores envolvidos nos processos de decisão, permite conhecer a forma como os indivíduos, grupos e organizações são condicionados pelos vários factores 
domésticos, nomeadamente os factores eleitorais, a opinião pública, os grupos de pressão e as preferências ideológicas (Holsti, 2006).

Em suma, a política externa é uma área abrangente cujo enfoque inclui questões diversas, como segurança, economia, ambiente, e cultura. A agenda é, por isso, densa, e as burocracias e grupos que apoiam o processo de formulação e decisão cruzam diferentes valências para poderem responder à multi-dimensionalidade associada à política externa. Paralelamente ao quadro institucional, variáveis objectivas como localização geoestratégica, população e recursos humanos, capacidade militar, económica e de inovação tecnológica, bem como factores de cariz subjectivo (incluindo motivações, identidade, valores, percepções) conjugam-se na formulação, decisão e implementação da política externa, com diferentes matrizes a caracterizarem diferentes actores. Além do mais, os objectivos de política externa, fundamentalmente assentes em interesses nacionais, são modelados de acordo com estes factores e com a interacção destas componentes com os arranjos do sistema internacional, exigindo ajustes variados e não permitindo uma projecção dos interesses e objectivos dos Estados sem limites. São estes múltiplos modelos, actores e dinâmicas que procuramos identificar, descrever e explicar nas páginas seguintes.

\section{Modelos teóricos}

Os assuntos de política externa são muitas vezes abordados de forma ligeira e informal, sem grandes considerações teóricas. Contudo, análises mais profundas dos eventos revelam um grau de complexidade que exige uma maior compreensão teórica. De facto, os estudos realizados pelos investigadores de política externa «evidenciam características regulares e previsíveis que reflectem pressupostos nem sempre reconhecidos sobre o carácter dos desafios, as categorias nas quais os problemas devem ser considerados, os tipos de provas relevantes e os determinantes das ocorrências» (Allison e Zelikow, 1999: 4). Consequentemente, estes pressupostos estão na base dos diferentes modelos teóricos que auxiliam os investigadores a melhor compreender os eventos políticos internacionais, nomeadamente 
identificando os factores determinantes mais relevantes das ocorrências, bem como as circunstâncias em que determinados factores conduziram a um determinado desfecho em vez de outro.

Esta secção identifica os principais modelos teóricos relativos aos processos de formulação e decisão em política externa. Note-se que apesar de apresentados em secções distintas, estes modelos não são necessariamente excludentes, havendo consenso na bibliografia relativamente à interacção destas diferentes abordagens numa explicação compreensiva dos processos. O quadro que se segue sintetiza as principais linhas caracterizadoras destes modelos para uma mais fácil leitura das secções seguintes.

\begin{tabular}{|c|c|c|c|c|}
\hline & Actor Racional & $\begin{array}{l}\text { Organizações } \\
\text { Burocráticas }\end{array}$ & $\begin{array}{c}\text { Pequenos } \\
\text { Grupos }\end{array}$ & Líderes \\
\hline $\begin{array}{c}\text { Actores } \\
\text { envolvidos } \\
\text { na decisão } \\
\text { de política } \\
\text { externa }\end{array}$ & $\begin{array}{l}\text { Estado age } \\
\text { como decisor } \\
\text { racional único }\end{array}$ & $\begin{array}{c}\text { Organizações } \\
\text { burocráticas } \\
\text { formais do } \\
\text { Estado }\end{array}$ & $\begin{array}{c}\text { Pequeno } \\
\text { número de } \\
\text { indivíduos } \\
\text { (variável) junto } \\
\text { da liderança }\end{array}$ & $\begin{array}{c}\text { Líderes } \\
\text { individuais }\end{array}$ \\
\hline $\begin{array}{l}\text { Dinâmicas } \\
\text { do modelo } \\
\text { de decisão }\end{array}$ & $\begin{array}{c}\text { Identificar } \\
\text { interesse } \\
\text { nacional; } \\
\text { Identificar } \\
\text { opções; } \\
\text { Análise custo/ } \\
\text { benefício das } \\
\text { opções; } \\
\text { Escolher } \\
\text { política que } \\
\text { melhor serve } \\
\text { o interesse } \\
\text { nacional }\end{array}$ & $\begin{array}{c}\text { Organizações } \\
\text { agem com base } \\
\text { em processos } \\
\text { estandardizados; } \\
\text { Interesses } \\
\text { determinados } \\
\text { para organização } \\
\text { a que se } \\
\text { pertence; } \\
\text { Negociações } \\
\text { para determinar } \\
\text { política }\end{array}$ & $\begin{array}{c}\text { Interacção } \\
\text { dinâmica entre } \\
\text { os diversos } \\
\text { membros do } \\
\text { grupo; } \\
\text { Group think; } \\
\text { Imposição de } \\
\text { solução; } \\
\text { Internalização; } \\
\text { Compromisso } \\
\text { negocial }\end{array}$ & $\begin{array}{c}\text { Decisão } \\
\text { resultante } \\
\text { da escolha } \\
\text { individual; } \\
\text { Apreciação } \\
\text { subjectiva da } \\
\text { situação; } \\
\text { Processos } \\
\text { cognitivos }\end{array}$ \\
\hline $\begin{array}{l}\text { Origens } \\
\text { e fontes } \\
\text { teóricas }\end{array}$ & $\begin{array}{l}\text { Teoria da } \\
\text { utilidade } \\
\text { esperada }\end{array}$ & $\begin{array}{c}\text { Teoria } \\
\text { organizacional; } \\
\text { Sociologia das } \\
\text { burocracias; } \\
\text { Política } \\
\text { burocrática }\end{array}$ & $\begin{array}{c}\text { Psicologia } \\
\text { social; } \\
\text { Sociologia } \\
\text { dos pequenos } \\
\text { grupos }\end{array}$ & $\begin{array}{l}\text { Psicologia } \\
\text { cognitiva; } \\
\text { Dissonância } \\
\text { cognitiva; } \\
\text { Dinâmica } \\
\text { psicológica }\end{array}$ \\
\hline
\end{tabular}

Quadro 1. Modelos de formulação e decisão em política externa 


\section{O Estado unitário e o processo de decisão racional}

A abordagem tradicional parte do princípio de que os Estados são agentes unitários e monolíticos na formulação e execução das suas políticas externas; e da existência de uma dicotomia entre a política externa e a política interna. Nesta perspectiva, a política interna é encarada como uma esfera distinta e independente da política externa, sendo o principal problema de análise a necessidade governamental de manter a autonomia e a integridade do Estado face à possibilidade de agressões exteriores (os factores externos são determinantes do comportamento dos Estados). A perspectiva tradicional assume, deste modo, que a política externa é formulada de forma homogénea e unitária, em conformidade com os elementos de poder e com base na definição do interesse nacional. Partindo desta perspectiva, os cálculos estratégicos sobre segurança nacional são os principais determinantes das escolhas dos decisores políticos; a política interna e o processo de formulação política são preocupações secundárias. De acordo com este mapa mental, os líderes que fazem a política externa, os tipos de governo que lideram, as características das suas sociedades, e as suas condições económicas e políticas internas não são relevantes.

Aqueles que estudam o processo de decisão e aconselham os decisores políticos sobre formas de melhorar as suas qualidades políticas, descrevem a racionalidade como uma sequência de actividades de decisão que envolvem os seguintes passos: 1) reconhecimento e definição do problema; 2) selecção de objectivos; 3) identificação de alternativas; 4) escolha a partir de um leque de várias opções; e 5) selecção racional da alternativa que melhor poderá levar ao objectivo pretendido. De acordo com a teoria da utilidade esperada de von Neumann, a racionalidade do actor (Estado) permite-lhe escolher entre as diferentes alternativas e calcular a melhor forma para atingir os seus objectivos. Aplicado à política externa, o modelo da racionalidade implica que o Estado aja intencionalmente, motivado por objectivos claramente definidos, demonstrando capacidade para ordenar as suas opções e preferências e maximizar a utilidade da sua escolha (Mintz e DeRouen Jr., 2010). A crise dos mísseis de Cuba de 
$1962^{1}$ ilustra o modo como as decisões dos EUA foram conformes a um processo racional. Uma vez descoberta a presença de mísseis soviéticos em Cuba, o Presidente John F. Kennedy pediu ao grupo de crise criado para proceder a um levantamento exaustivo relativo aos perigos e possíveis cursos de acção. Foram definidas seis opções: nada fazer; exercer pressão diplomática; fazer uma aproximação secreta ao líder cubano Fidel Castro; invadir Cuba; lançar um ataque aéreo cirúrgico contra os mísseis; e impor um bloqueio à ilha. Os objectivos tiveram de ser ordenados por ordem de preferência antes da escolha poder ser feita. Seria o objectivo de retirada dos mísseis soviéticos retaliação contra Castro ou pretensão de manutenção da balança de poder? Ou será que os mísseis significavam uma pequena ameaça aos interesses vitais dos EUA? Até que os mísseis fossem considerados como uma ameaça séria à segurança norte-americana, 'nada fazer' não podia ser eliminado como opção. Uma vez acordado que a remoção dos mísseis era o objectivo, a discussão dos conselheiros voltou-se para a avaliação das opções do ataque cirúrgico e do bloqueio. Esta última foi a escolhida devido às suas presumidas vantagens. Permitia aos EUA uma demonstração de firmeza, enquanto mantendo flexibilidade relativamente a novas opções de ambos os lados.

Apesar da aplicação aparente da racionalidade a esta crise, o modelo de decisão racional é mais um padrão idealizado segundo o qual se avaliam preferências, do que propriamente uma descrição precisa do comportamento no mundo real. Theodore Sorensen, que participou nas deliberações da crise de Cuba, escreveu não só sobre os passos da administração Kennedy seguindo o processo de escolha racional, como também sobre a facilidade com que o processo de decisão real se afasta dele: "não se pode dar cada passo segundo uma ordem. Os factos poderão ser duvidosos ou estar em contradição; várias políticas, todas boas, podem entrar em conflito. Vários meios, todos maus, podem ser tudo o que está em aberto. Os julgamentos de valor podem ser diferentes. Os objectivos definidos podem ser imprecisos.

\footnotetext{
1 Os exemplos da crise dos mísseis de Cuba que servem para ilustrar os diferentes modelos teóricos seguem a proposta de Kegley e Wittkopf (1995).
} 
Pode haver muitas interpretações sobre o que está certo, o que é possível, e o que é no interesse nacional» (Kegley e Wittkopf, 1995: 49).

Apesar das virtudes oferecidas pela escolha racional, os impedimentos à sua realização são substanciais. Alguns são humanos; derivam de deficiências nos serviços de informação, capacidade, e aspirações e necessidades psicológicas daqueles que tomam decisões de política externa sob condições de incerteza. Outros são organizacionais pois a maior parte das decisões são tomadas em grupo. Em resultado, a maior parte das decisões requerem assentimento do grupo quanto ao interesse nacional e ao curso de acção a seguir. Chegar a um acordo não é fácil, dada a discordância sobre objectivos ou preferências, e sobre os resultados prováveis de opções alternativas. Por exemplo, o reconhecimento do problema é muitas vezes adiado. Grandes quantidades de informação para trabalhar em tempo escasso ou informação insuficiente ou inadequada para definir problemas emergentes de forma cuidada, condicionam o processo de formulação política racional.

Uma vez que os decisores políticos trabalham constantemente com agendas sobrecarregadas e prazos curtos, a procura de opções políticas é raramente exaustiva. Como Kissinger afirmava, "há pouco tempo para os líderes reflectirem. Estão presos numa batalha sem fim onde o urgente se sobrepõe constantemente ao importante. A vida pública de cada figura política é uma luta contínua para salvar um elemento de escolha da pressão das circunstâncias» (Secretário de Estado norte-americano, 1979, em Kegley e Wittkopf, 1995: 50). Na fase da escolha, em vez de seleccionarem uma opção ou conjunto de opções com as melhores hipóteses de sucesso, os decisores geralmente decidem quando surge uma alternativa que parece melhor que as consideradas anteriormente. Em vez da optimização, dá-se apenas uma satisfação, através de uma escolha que satisfaça os requisitos mínimos, evitando opções mais arriscadas.

Ou seja, em certas circunstâncias, os governos tomam decisões como se estivessem a seguir a norma da racionalidade meios-fins e escolhem a alternativa que melhor lhes permite atingir os objectivos ou promover os valores dos decisores. A dicotomia entre os pressupostos da racionalidade e da irracionalidade no comportamento de indivíduos, grupos e governos constitui, assim, uma das dimensões mais persistentes e problemáticas. 
A «concepção sinóptica» da tomada de decisões que parte do princípio de que os políticos colocam perante si todas as alternativas possíveis avaliando, a partir da sua hierarquia de preferências, todas as consequências das mudanças sociais inerentes às diversas acções em consideração, não se adequa à realidade. Pressupõe uma omnisciência e uma espécie de análise abrangente demasiado dispendiosa e que a pressão do tempo normalmente não permite. Cada solução tem de estar limitada a uma série de factores, incluindo as capacidades individuais de resolução de problemas, a informação disponível, o custo da análise (em pessoal, recursos e tempo) e a impossibilidade prática de separar os factos dos valores.

Herbert Simon (1955: 13) foi um dos principais críticos do modelo clássico da tomada racional de decisões, postulando um mundo de «racionalidade limitada». Substituiu o conceito de maximização ou optimização do comportamento pelo de comportamento satisfatório. Este pressupõe que os políticos não elaboram uma matriz com todas as alternativas disponíveis, os prós e contras de cada uma delas e as avaliações de probabilidade das consequências esperadas. Em vez disso, as unidades de decisão examinam, de forma sequencial, as alternativas disponíveis até chegarem a uma que corresponda aos seus níveis mínimos de aceitabilidade. Por outras palavras, os indivíduos vão rejeitando as soluções que os não satisfazem até encontrarem uma solução suficiente e consensualmente satisfatória que lhes permita agir. Apesar de os decisores conseguirem absorver rapidamente grandes quantidades de informação sob grande pressão, e assumir riscos calculados com base num planeamento ponderado, muitas vezes o grau de racionalidade tem pouca relação com o mundo onde os oficiais conduzem as suas deliberações. Apesar da formulação racional da política externa ser mais um ideal do que uma descrição da realidade, parece útil aceitar a racionalidade como imagem do modo como o processo de decisão se deve processar e como uma descrição dos elementos chave de como pode funcionar.

O modelo do actor racional assume que os estados unitários são os intervenientes-chave e que agem de forma racional, calculando os custos e os benefícios inerentes às várias escolhas políticas, na procura da escolha que maximize a sua utilidade. Este modelo encontra laços estreitos com o realismo clássico e o neo-realismo ou realismo estruturalista. Apesar disso, 
institucionalistas liberais como Keohane, juntamente com teorizadores da paz democrática como Doyle, são vistos como comungando do essencial do modelo do actor racional. De qualquer modo, o campo liberal e pluralista tende a juntar ao modelo, quadros de referência centrados na máquina e políticas governativas: os processos organizacionais - segundo modelo de Allison, que consiste em identificar as organizações governamentais relevantes envolvidas numa crise, determinando depois os interesses e os procedimentos operacionais standard que influenciam o comportamento das organizações; e os processos burocráticos - que analisamos em seguida e que se prendem com as políticas internas, não tendo a ver tanto com escolhas ou com resultados, mas mais com os jogos negociais e de influência no seio da estrutura hierárquica governativa. Ou seja, enquanto o actor racional procura maximizar os objectivos estratégicos nacionais; as organizações comportam-se de acordo com os procedimentos operacionais estandardizados; e as burocracias envolvem-se em compromissos, negociações, coligações e competição.

As organizações burocráticas e os pequenos grupos no processo de decisão da política externa

No mundo de hoje, as relações extensivas em termos políticos, militares e económicos exigem dependência de grandes organizações especializadas que possam melhor recolher e tratar informação. Os líderes apoiam-se nelas perante escolhas críticas ao nível da política externa, sendo que se poderá afirmar que a maior parte das decisões de política externa são tomadas num contexto organizacional. Sem desvalorizar a noção de liderança, Max Weber escreveu que, "num estado moderno, o dirigente é necessária e inevitavelmente a burocracia, pois o poder não é exercido, nem por discursos parlamentares, nem por enunciados monárquicos, mas sim através da rotina administrativa» (Max Weber in Dougherty: 707). Embora sejam os dirigentes quem decide o que fazer, é a burocracia que decide como se deve proceder. Decidir como fazer pode, por sua vez, moldar o que fazer. Por isso, as burocracias são de importância vital no estudo da tomada de decisões. 
Aliás, segundo Vertzberger (2002) o que distingue as organizações burocráticas é exactamente a sua dependência em procedimentos que auxiliam na coordenação e na execução de tarefas específicas.

Os decisores dependem de conselheiros, chefes de departamentos e de agências governamentais e do seu pessoal burocrático para obterem informações fundamentais relativamente às decisões da política externa, o que não invalida que em muitos casos haja discordância na interpretação das informações e acontecimentos. As restrições orçamentais podem ser um factor determinante ao nível da recolha e qualidade da informação, levando mesmo a competição interna no seio das burocracias por mais recursos. Além do mais, as burocracias podem moldar as perspectivas dos dirigentes políticos e da opinião pública sobre assuntos de política externa, podendo mesmo influenciar o curso dos acontecimentos. A «unidade de decisão legítima» - unidade capaz de atribuir os recursos necessários e de produzir uma decisão investida de autoridade, pode assumir diferentes formatos: um dirigente dominante (como Castro), um único grupo onde os elementos se confrontam directamente (Politburo ou Conselho de Segurança Nacional) ou múltiplos actores autónomos (sistemas parlamentares).

As burocracias visam melhorar a eficiência e a racionalidade ao conferirem a responsabilidade de diferentes tarefas a diferentes pessoas, definindo regras e procedimentos operacionais que especificam o modo como as tarefas devem ser executadas, e a divisão de autoridade entre diferentes organizações para evitar a duplicação de esforços. Ainda permitem o planeamento avançado com o objectivo de determinar necessidades a longo prazo e os meios de as alcançar. Deste modo, a presença destas organizações poderá resultar numa multiplicidade de opções, melhorando as hipóteses de um maior número de alternativas ser considerado, bem como de adopção de procedimentos de resposta estandardizados. Por exemplo, quando a administração Kennedy optou pela imposição da quarentena naval a Cuba durante a crise dos mísseis para prevenir novos carregamentos de mísseis, a marinha norte-americana pôde pôr em prática a decisão presidencial de acordo com procedimentos anteriormente definidos. Contudo, estas rotinas limitam a opção de escolhas políticas viáveis a partir das quais os decisores políticos poderão seleccionar as suas opções. Mais do que expandir o número de 
alternativas em termos de políticas de forma consistente com a lógica da decisão racional, aquilo que as organizações estão preparadas para fazer molda o que é e o que não é considerado possível. Na crise de Cuba, o ataque aéreo cirúrgico com vista a destruir os mísseis soviéticos então em construção foi vista como alternativa possível ao bloqueio, mas quando a força aérea admitiu que não poderia garantir 100\% de sucesso na operação, essa alternativa foi posta de lado. Assim, as capacidades organizacionais moldaram claramente as opções da administração Kennedy para alcançar o seu objectivo de retirar os mísseis soviéticos de solo cubano.

Para além da influência que as organizações burocráticas exercem nas escolhas dos líderes políticos, podem afectar o ambiente de decisão, assumindo muitas vezes posições destinadas a aumentar a sua influência face a outras agências. Para proteger os seus interesses, as organizações burocráticas procuram reduzir a interferência dos líderes políticos a quem reportam, bem como a de outras agências governamentais, e chegam mesmo a não partilhar informação relativa a actividades internas. Adicionalmente, cada burocracia desenvolve uma forma dominante de olhar a realidade resultante da própria solidariedade e coesão que geralmente se gera no interior de pequenos grupos. Este tipo de perfilamento institucional acaba por reduzir a criatividade e o pensamento independente, encoraja o ancoramento em procedimentos operacionais padronizados e dá preferência a procedimentos já utilizados em vez de novas opções face a novos desafios.

Novamente recorrendo à crise dos mísseis de Cuba de 1962, enquanto o Presidente Kennedy procurou dirigir a acção e negociação, a sua burocracia em geral, e a marinha em particular, estavam de facto a controlar os acontecimentos. A marinha escolheu obedecer às ordens que quis e ignorar as outras. Assim, após discussão com a marinha, Kennedy ordenou que a linha do bloqueio se aproximasse de Cuba de tal modo que os soviéticos tivessem mais tempo para se retirarem. Tendo perdido na discussão com o presidente, a marinha simplesmente ignorou a sua ordem. Sem o conhecimento do presidente, a marinha estava envolvida na pressão aos submarinos soviéticos para que viessem à superfície, muito antes de Kennedy autorizar qualquer contacto com os navios soviéticos. E apesar da ordem presidencial para terminar com acções e informações provocadoras, um 
avião norte-americano entrou no espaço aéreo soviético no auge da crise. Quando Kennedy se apercebeu que não estava no controlo da situação, pediu ao secretário da defesa para averiguar o que se estava a passar. McNamara fez a sua primeira visita ao posto de comando da marinha no Pentágono. Num debate acalorado, o chefe das operações navais sugeriu a McNamara que regressasse ao seu posto de trabalho e deixasse a marinha gerir o bloqueio.

As organizações burocráticas não são as únicas estruturas a participar e auxiliar os líderes nos processos de decisão e implementação da sua política externa. Há muito que se reconheceu o papel dos pequenos grupos na formulação da política externa. Embora os grupos possam variar em tamanho, composição, importância e funções, eles dispõem de algumas características comuns (Vertzberger, 2002): partilham uma série de valores, atitudes e crenças elementares; a maioria dos membros partilha de uma ligação efectiva; e dividem os papéis formais e informais entre si. Estes atributos geram dinâmicas muito particulares que podem ter efeitos significativos no conteúdo e na qualidade das decisões em que participam (Holsti, 2006).

Os pequenos grupos são úteis para lidar com as complexidades da política internacional, contribuindo com uma pletora de perspectivas e com a possibilidade de um debate mais enriquecedor. Igualmente, a relação efectiva típica dos pequenos grupos oferece várias formas de apoio aos decisores, nomeadamente ao nível emocional. Todavia, há também a tendência para limitarem os processos de decisão através de dinâmicas propícias à conformidade. Uma das dinâmicas mais significativas é a do groupthink. Segundo Irving Janis (1971) este fenómeno refere-se à forma de pensar que ocorre quando a procura de concordância entre os indivíduos se torna tão dominante no seio de um grupo que tende a impor-se sobre as apreciações realistas de outras alternativas de acção. O groupthink é reforçado pelo desejo dos indivíduos em serem aceites no grupo, assim as perspectivas e interpretações que possam contrariar as percepções comuns do grupo acabam por ser relegadas para segundo plano ou abandonadas por completo. Em geral, o groupthink apresenta como características (Vertzberger, 2002): prosseguir uma avaliação racional de modo a ignorar informações contraditórias; alguns membros do grupo auto-nomeiam-se para proteger o grupo 
de informação dissonante; o grupo acredita profundamente na sua rectidão, censurando quaisquer dúvidas relativamente a esta; excesso de optimismo que predispõe acções com elevados riscos; os adversários são concebidos de forma estereotipada e considerados altamente perigosos ou ignaros; os membros desviantes são pressionados directamente permitindo consenso no grupo sobre a existência de uma percepção comum.

Contudo, por vezes podem ocorrer divergências no seio dos grupos, exigindo alternativas para resolver o impasse. Em primeira instância, os principais decisores no grupo podem impor a sua preferência, caso tenham poder para tal. Outra forma de resolução acontece quando existe uma maioria de elementos a favor de uma determinada interpretação, existindo uma tendência para os elementos minoritários aceitarem a decisão e em muitos caso internalizá-la. A internalização da decisão maioritária depende em grande parte dos atributos do grupo, designadamente a distribuição de poder, o papel que cada elemento desempenha no grupo, o estatuto de cada elemento e as ligações afectivas entre os indivíduos (Vertzberger, 2002). Por último, quando não existem elementos com poder suficiente para impor uma decisão e não existe uma maioria clara, as resoluções das incongruências derivam de um compromisso que se atinge através das premissas comuns existentes entre os diferentes elementos do grupo.

Não surpreendentemente, os vários participantes das deliberações que levam a escolhas políticas, muitas vezes definem temas e favorecem alternativas políticas que reflectem a sua afiliação organizacional ou grupo. Assim, os diplomatas profissionais tipicamente favorecem soluções diplomáticas para os problemas, enquanto os agentes militares favorecem a opção militar. Mais do que se tratar de uma escolha maximizante de valor, então, o processo de formulação política é em si mesmo intensamente político. Assim, face a uma decisão, mais do que pressupondo a existência de um actor unitário, é necessário identificar jogos e jogadores, e apresentar coligações, exigências e compromissos. Desta perspectiva, a decisão de impor um bloqueio a Cuba foi tanto produto de quem favoreceu a escolha como de qualquer lógica inerente que a possa ter recomendado. Quando Robert Kennedy (irmão do presidente e procurador geral), Theodore Sorensen (conselheiro presidencial) e o secretário da defesa Robert McNamara se uniram em de- 
fesa do bloqueio, formou-se uma coligação dos principais conselheiros do presidente e com os quais ele mais se compatibilizava.

Todavia, Alexander George defende que as decisões acertadas não têm de seguir obrigatoriamente processos racionais e consensuais (Renshon e Renshon, 2008). Embora não negando a importância dos grupos nos processos de decisão de política externa, George salienta que nem todas as decisões são tomadas em grupo e em muitos casos as decisões executivas não dependem dos consensos nos grupos. Este argumento reforça o papel determinante que a psicologia dos líderes tem nas dinâmicas de grupo e nos processos de decisão. Enquanto alguns líderes dependem dos grupos para informar e sustentar as suas decisões, outros conseguem determinar de forma autónoma as políticas a seguir. Desta forma, a necessidade de analisar o papel dos líderes no processo de decisão é indispensável.

\section{O papel dos líderes no processo de decisão da política externa}

Os líderes, e o tipo de liderança que exercem, moldam o modo como é feita a política externa e o consequente comportamento dos Estados na política internacional. Este modelo equaciona a acção nacional com as preferências e iniciativas dos mais altos oficiais dos governos nacionais, uma imagem clara quando rotineiramente ligamos os nomes de líderes a políticas (por exemplo, Doutrina Monroe ou Doutrina Brejnev), e quando atribuímos a maior parte dos sucessos e falhanços na política externa aos líderes no poder na altura da ocorrência. Há, no entanto, amplas divergências entre aquilo que os líderes muitas vezes fazem e aquilo que é esperado deles.

Podemos explicar esta divergência, em parte, ao distinguirmos entre racionalidade procedimental e racionalidade instrumental. A racionalidade procedimental sustenta a visão da política mundial no mesmo tipo de cálculos frios, baseados num balanceamento cuidado de todos os cursos de acção alternativos possíveis. A racionalidade instrumental, por outro lado, constitui uma visão mais limitada de racionalidade. Diz simplesmente que os indivíduos têm preferências, e quando são confrontados com duas ou mais alternativas, escolherão a que lhes parece conter o desenrolar prefe- 
rido. Em oposição à definição de racionalidade procedimental, a definição instrumentalista não oferece avaliações normativas das preferências de um actor, por muito repreensíveis ou mal-fundadas que sejam, baseando então a sua explicação na questão dos objectivos. As implicações destas diferenças aparentemente semânticas são importantes. Demonstram que a racionalidade tem limites, o que nem sempre é assumido quando o modelo de actor racional descrito acima é aplicado a situações reais. Também sugerem que os indivíduos podem actuar racionalmente (no sentido instrumentalista) ao mesmo tempo que o processo de decisão e o seu produto surgem de forma irracional.

Apesar da popularidade deste modelo, não devemos conferir demasiada importância aos líderes individuais. A sua influência é capaz de ser muito mais subtil do que as impressões populares nos têm feito crer. A maioria dos líderes age sob uma variedade de constrangimentos políticos, psicológicos e circunstanciais que limitam aquilo que podem alcançar e reduzem o seu controlo dos eventos. Nas palavras de Lincoln, «eu não controlei os acontecimentos, os acontecimentos é que me controlaram a mim» (1864). A questão passa pelo facto de os líderes não controlarem completamente uma situação, e a sua influência ser severamente circunscrita. Assim, a personalidade e as preferências políticas pessoais não determinam de forma directa a política externa. A questão relevante, então, não é se as características pessoais do líder fazem a diferença, mas sob que condições as suas características são determinantes. Em geral, o impacto das características pessoais de um líder na política externa aumenta quando a sua autoridade e legitimidade são amplamente aceites pela população ou, em regimes autoritários ou totalitários, quando os líderes são protegidos de amplas críticas públicas. Além do mais, alguns tipos de circunstâncias favorecem o potencial impacto dos indivíduos. Entre elas encontram-se novas situações que libertam os líderes das abordagens convencionais; situações complexas que envolvem um grande número de factores diferentes; e situações isentas de sanções sociais que permitem liberdade de escolha porque as normas que definem o leque de opções permissíveis não são claras.

A auto-imagem do líder - a crença de uma pessoa na sua capacidade para controlar os acontecimentos de forma política (conhecida como 
«eficácia política») - também influenciará o grau em que os valores pessoais e as necessidades psicológicas governam o processo de decisão. Por outro lado, quando o sentido de auto-importância ou eficácia está ausente, isto minará a capacidade do líder para lidar com e iniciar mudanças nas políticas. Contudo, esta ligação não é directa. O desejo das populações por uma liderança forte também a afecta. Quando a opinião pública produz uma preferência forte por um líder poderoso, e quando o chefe de Estado tem uma necessidade excepcional de admiração, por exemplo, a política externa irá mais certamente reflectir as necessidades próprias do líder. Por exemplo, a personalidade de Guilherme II foi ao encontro do desejo do povo alemão de um líder simbólico poderoso, e as preferências públicas alemãs influenciaram a política externa da Alemanha durante o seu reinado, que acabou com a Primeira Guerra Mundial.

A quantidade de informação disponível sobre situações particulares é também importante. Sem informação pertinente, as políticas poderão ser baseadas nos gostos e preferências dos líderes. Por outro lado, quanto mais informação um indivíduo tiver sobre os acontecimentos internacionais, menos provável será que o seu comportamento se baseie em influências pouco lógicas. De forma similar, o timing da chegada de um líder ao poder é importante. Quando um indivíduo assume pela primeira vez uma posição de liderança, os requisitos formais de tal posição são menos propensos a circunscrever aquilo que pode ou não fazer. Isto é especialmente verdade no período inicial do mandato, durante o qual estão livres de críticas e pressões excessivas. Além do mais, quando um líder assume governo após um acontecimento dramático (como o assassínio do seu antecessor), pode definir políticas quase sem impedimento pois nestes períodos o eleitorado geralmente abstém-se de críticas.

Uma crise nacional é uma circunstância especialmente propensa a aumentar o controlo do líder sobre a formulação da política externa. O processo de decisão durante uma crise é tipicamente centralizado e gerido exclusivamente no topo da liderança. Falta muitas vezes informação crucial e os líderes vêem-se como responsáveis pelos desenvolvimentos. De forma não surpreendente, então, os nomes de grandes líderes da história, como Napoleão Bonaparte, Winston Churchill, e Franklin D. Roosevelt, emergem facilmente em períodos de grande turbulência. Os líderes são heróis capazes 
de determinar os acontecimentos. O momento pode fazer a pessoa, mais do que a pessoa fazer o momento, no sentido em que a crise pode libertar o líder dos constrangimentos que normalmente iriam inibir a sua capacidade de controlar acontecimentos ou engendrar mudanças na política externa. Na história abundam exemplos de líderes políticos que surgem em diferentes momentos e lugares para tomarem papéis decisivos que mudam o rumo da história mundial (por exemplo, Gorbachov na União Soviética).

No entanto, o impacto pessoal do líder varia com o contexto, e muitas vezes o contexto é mais influente que o líder. A questão prende-se em saber se são os tempos que conduzem à emergência de grandes líderes, ou ao invés, se grandes pessoas seriam líderes determinantes independentemente de quando e onde vivessem. Este modelo parece simplista na sua explicação da forma como os Estados reagem, uma vez que a maior parte dos líderes mundiais seguem as regras do jogo da política internacional, que sugerem que a forma como os Estados lidam com os ambientes externos é muitas vezes menos influenciada pelas pessoas na liderança do que por outros factores. Deste modo, este modelo parece claramente complementar as abordagens anteriores, somando-lhes o ingrediente fundamental relativo ao papel da liderança na política externa.

\section{Determinantes e condicionantes do processo de decisão de política externa}

Como referido, a política externa envolve uma pletora de realidades complexas que dificultam a tomada de decisões. Nesta secção analisamos alguns dos principais determinantes e condicionantes do processo de decisão de forma a compreender as dinâmicas mais subtis que estão envolvidas na formulação de política externa dos diversos Estados. Porém, antes é necessário identificar os diversos tipos de decisões envolvidos em política externa (Mintz e DeRouen Jr., 2010):

- Decisões singulares - decisão isolada, sem estar contextualizada num processo mais amplo. Embora sejam raras em política internacional, algumas decisões são estudadas pelos investigadores e analistas políticos como actos isolados, como são o caso da decisão americana 
para não ratificar o Protocolo de Quioto ou a decisão americana para não auxiliar as tropas francesas em Dien Bien Phu em 1954;

- Decisões estratégicas interactivas - interacção entre pelo menos dois actores cujas decisões afectam e são afectadas reciprocamente. Neste caso, a decisão de um actor vai afectar a decisão do outro actor ou vice-versa. O modelo clássico do Dilema do Prisioneiro atesta este tipo de situações;

- Decisões sequenciais - envolvem uma sequência de decisões interrelacionadas, como por exemplo no caso americano de decidir invadir ou não o Iraque, ocupar ou não o país, aumentar ou diminuir a presença de forças militares, retirar ou comprometer mais activos, término da operação;

- Decisões sequenciais interactivas - sequência de decisões condicionadas pela interacção de pelo menos dois actores. Exemplos tradicionais deste tipo de decisões são as corridas armamentistas, nas quais os diferentes Estados respondem de forma recíproca às decisões dos seus adversários para aumentar a sua capacidade bélica.

Podem-se ainda destacar várias formas de decisão (Mintz e DeRouen Jr., 2010):

- Decisões unilaterais - tomadas pela iniciativa exclusiva de uma parte, sem considerar a vontade dos outros actores. A decisão da Líbia para abandonar o seu programa nuclear em 2003 ou a decisão dos EUA para não ratificar o Tratado de Quioto são exemplos ilustrativos;

- Decisões negociadas - resultam da interacção de pelo menos dois actores que chegam a um acordo sobre a forma de agir. Um exemplo elucidativo foi a decisão da Coreia do Norte de abandonar o seu programa nuclear em troca de ajuda externa depois de um longo processo negocial multilateral;

- Decisões forçadas - são determinadas pela pressão ou ameaça de coacção de um ou mais actores externos. Um exemplo característico foi a pressão política e económica exercida sobretudo pelos EUA e a Rússia para forçar a retirada das forças Britânicas, Francesas e Israelitas que ocuparam o Canal do Suez em 1956; 
- Decisões estruturadas - resultantes da repetição e rotinas formalmente estabelecidas. Estas decisões são típicas das organizações burocráticas e envolvem um elevado grau de certeza. A elaboração dos orçamentos de defesa dos diferentes Estados resulta, regra geral, de processos padronizados desenvolvidos pelas respectivas organizações e envolvem pouca inovação e incerteza;

- Decisões semi-estruturadas - envolvem um maior grau de risco, pois um ou mais factores não estão previstos nos processos estabelecidos;

- Decisões não-estruturadas - nestes casos, alguns factores estruturais como os objectivos e opções podem não estar suficientemente especificadas, impossibilitando a aplicação de soluções disponíveis ou de rotina. A decisão da intervenção militar americana no Afeganistão depois do 11 de Setembro enquadra-se neste perfil, pois a complexidade da situação não tinha sido convenientemente antecipada pelas organizações responsáveis e não havia planos preparados para responder de forma imediata à ameaça (Woodward, 2005).

Contudo, o processo de decisão de política externa não é um procedimento simples e linear. Pelo contrário, a complexidade é a característica dominante do processo de decisão (Renshon e Renshon, 2008). Para além da informação subjacente à decisão ser sempre imparcial e deficiente, a ambiguidade e incerteza são próprias do ambiente de decisão. Existem inúmeras variáveis no ambiente de decisão que agravam os obstáculos que os decisores enfrentam e dificultam a aplicação de estratégias decisórias optimizadas e das quais se destacam os constrangimentos temporais, contextos dinâmicos e interactivos, riscos envolvidos e stress sobre os decisores (Mintz e De Rouen, Jr., 2010; Renshon e Renshon, 2008). A complicar esta situação está o ambiente político internacional que é igualmente complexo devido a um conjunto de características particulares que o tornam opaco e incerto e dos quais se destacam (Vertzberger, 2002):

- Multiplicidade de actores - existem inúmeros actores activos no ambiente político internacional - por exemplo, Estados, organizações internacionais, actores não-estatais - que produzem uma quantidade considerável de estímulos que são difíceis de ser captados e desco- 
dificados eficientemente pelos diversos sistemas de processamento de informação;

- Assimetrias na acessibilidade tecnológica - embora as tecnologias de informação e comunicação tenham assistido a uma autêntica revolução nos últimos anos, nem todas as organizações de informação têm a mesma capacidade para analisar e interpretar a quantidade de informação recebida;

- Decepção - muitos actores utilizam a decepção como uma táctica para iludir ou manipular outros actores, dificultando a distinção entre estímulos e mensagens autênticas ou simuladas;

- Secretismo - muitos actores guardam muita informação em segredo impedindo o acesso de outros actores à informação necessária para proceder a uma avaliação correcta da situação;

- Inexistência de informação - há informação desejada e necessária que simplesmente não existe;

- Ambiguidade de conteúdo - a informação tende a ser susceptível de múltiplas interpretações, muitas contraditórias. A ambiguidade da informação pode resultar do seu próprio conteúdo ser pouco explícito ou o actor assumir que a decepção é uma regra do jogo político, criando a tendência para procurar significados alternativos na informação;

- Inconsistência de conteúdo - por vezes um actor pode apresentar mensagens diferentes e até contrárias conforme os públicos a que se dirige - i.e. público doméstico, elite doméstica, público opositor, elite opositora, elites noutros países, opinião pública mundial. Esta situação cria dificuldades em discernir qual a mensagem que representa as verdadeiras intenções do actor emissor;

- Ambiguidade da fonte - por vezes é difícil identificar a fonte de informação o que complica a relevância e importância da informação;

- Associação de vários assuntos - numa época onde a interdependência dos assuntos é cada vez maior, assiste-se a uma organização horizontal dos diferentes temas. Esta interdependência leva a que seja difícil distinguir quando é que as causas e consequências de um tema são afectadas ou influenciam outro; 
- Cinética - o ambiente político está em constante fluxo, obrigando a uma interpretação permanente das variáveis que se mantêm ou se alteram. Desta forma, a informação recebida tem de ser constantemente reinterpretada e avaliada;

- Modularidade - a informação pertinente às decisões de política externa tem de ser interpretada em conjunto. Todavia, não existe uma fórmula que determine qual a ordem e lógica subjacente à diferente informação recolhida para proceder à avaliação mais correcta. As diferentes organizações impõem sequências distintas nos dados avaliados resultando em interpretações e definições diferentes, se não mesmo contraditórias, das situações.

Porém, enquanto se reconhece que o ambiente no qual os decisores actuam é altamente complexo, outros factores contribuem de forma igualmente significativa para a complexidade do processo de decisão. Em seguida examinamos de forma heurística os factores mais determinantes no condicionamento das decisões de política externa. Sendo certo que não esgotamos os diversos factores que determinam e condicionam o processo de decisão de política externa de um Estado, identificamos os que prevalecem na bibliografia temática ${ }^{2}$ com enfoque nos grupos de interesse, comunidades epistémicas e opinião pública, e nos factores psicológicos, especialmente processos cognitivos e de representação.

\section{Grupos de interesse, comunidades epistémicas e opinião pública}

Os grupos de interesse, comunidades epistémicas e de peritos e a opinião pública são referidos na bibliografia como factores de análise fundamen-

2 Variáveis como localização geoestratégica, poder económico e militar, recursos naturais são referenciadas comummente como determinantes na formulação e decisão em política externa. Além do mais, a bibliografia identifica factores como as alianças, as corridas ao armamento, o nuclear ou o tipo de regime político como aspectos a ter em conta nas análises. Ver Doyle (1983), Foot (2006), Freedman (2004), Gray (2007), Ikenberry (2008), Levy (1981), Mintz e DeRouen Jr. (2010), Nye Jr. (2002), Saunders (2009), Wallace (1979). 
tais no estudo da política externa. Como referido na secção relativa aos modelos teóricos, estes factores podem ter um peso determinante nos processos de formulação e implementação de decisões, moldando, formatando e condicionando opções. De forma variada, estes influenciam, directa ou indirectamente, o processo de decisão de política externa.

Os grupos de interesse organizados representam variados interesses distintos. Um grupo muito influente representa os interesses económicos nacionais, onde organizações de trabalhadores e empresas dispõem de recursos importantes para influenciar os decisores políticos. Seja para proteger os seus postos de trabalho ou para consolidar e aumentar os seus negócios, estes grupos de interesse aplicam uma elevada pressão nos políticos e que se traduz na mobilização eleitoral e financeira dos seus constituintes (Jacobs e Page, 2005). Outros grupos organizados representam interesses mais específicos em termos de política externa. Os lobbies políticos associados a causas de outros Estados também condicionam os decisores políticos através dos inúmeros recursos de que dispõem. Um estudo recente testemunha o peso que o lobby israelita tem na formulação da política externa norte-americana (Mearsheimer e Walt, 2008). Composto por uma coligação informal de indivíduos e grupos, o lobby israelita tem mobilizado um nível assinalável de apoio material e diplomático para persuadir os decisores americanos a manterem uma política de apoio a Israel. Os autores argumentam que o poder do lobby assume proporções tão significativas que as políticas por si avançadas por vezes acabam por ser prejudiciais e contraproducentes para o próprio interesse nacional dos EUA (Mearsheimer e Walt, 2008).

Por sua vez, as comunidades epistémicas são compostas por uma «rede de profissionais com experiência e competência reconhecidas numa determinada área e uma autoridade reconhecida sobre um conhecimento de interesse político dentro dessa mesma temática» (Haas, 1992: 3). Embora as comunidades epistémicas compreendam geralmente grupos compostos por cientistas e académicos, também se referem a grupos constituídos por outros indivíduos que partilhem um conjunto de características comuns (Haas, 1992: 3), nomeadamente um conjunto de crenças normativas e princípios que fornecem uma base valorativa para a actividade social dos seus membros; a partilha de crenças sobre a causalidade central de um 
determinado problema e que estabelece a ligação entre as alternativas de acção política e os resultados desejados; noções partilhadas de validade, i.e. critérios intersubjectivos internamente definidos para avaliar e validar o conhecimento na sua área de especialização; e um projecto político comum que acreditam possa melhorar a situação em causa.

As comunidades epistémicas e os peritos influenciam a decisão política ao fornecer os decisores com reflexões e recomendações sobre as políticas a prosseguir, nomeadamente identificando causas, dinâmicas, objectivos e alternativas políticas inerentes aos eventos políticos internacionais. O Project for a New American Century (PNAC) reflecte estes preceitos. Fundado em 1997 por um pequeno conjunto de indivíduos de orientação conservadora, o PNAC foi moldando o debate de política externa no seio do Partido Republicano nos EUA. Inicialmente irradiado do palco principal do debate político, o PNAC conseguiu através da utilização de diversos recursos à sua disposição, principalmente a autoridade intelectual reconhecida dos seus membros em questões de política internacional, afirmar-se como um grupo de pressão altamente eficiente na influência do poder político. É hoje reconhecido que a afirmação contemporânea do poder militar americano e a sua orientação intervencionista e transformadora fruem de muitos dos princípios e orientações apontadas pelo PNAC (Chollet e Goldgeier, 2008).

Vários estudos demonstram que a opinião pública tem um impacto significativo no processo de decisão política. Os períodos de crise internacional são particularmente susceptíveis ao poder do sentimento popular. No seu estudo sobre a influência da opinião pública americana, Brulé e Mintz demonstram que os líderes moderam o uso da força quando há uma oposição popular generalizada, mas quando há uma maioria favorável os líderes geralmente optam por políticas mais agressivas (Mintz e DeRouen Jr., 2010). Contudo, a opinião pública é susceptível a alterações significativas. Se é certo que pode haver um inequívoco apoio público a uma qualquer política em determinado momento, tal não significa que essa mesma opinião não se altere de forma substancial em pouco tempo. Todavia, estudos aprofundados, abrangendo ciclos temporais relativamente longos, evidenciam uma maior estabilidade na opinião pública do que usualmente se pressupõe 
(Holsti, 2006; Jacobs e Page, 2005). De qualquer maneira, a sua influência não pode ser afastada, particularmente quando se considera a forma como os decisores percepcionam a vontade popular.

Estreitamente associado à opinião pública estão os meios de comunicação social. Em muitas situações os decisores aferem o apoio público através da cobertura que os meios de comunicação atribuem a determinado assunto (Breuning, 2007). Logicamente, o poder dos órgãos de comunicação é importante não só pela sua capacidade para direccionar a atenção do público, mas também dos decisores políticos. De facto, muitos estudos debruçam-se sobre o denominado «efeito CNN», procurando analisar a forma como os meios de comunicação têm influenciado as decisões políticas. Embora se mantenha um debate vivo sobre os modelos e metodologias mais apropriadas para averiguar o fenómeno, a importância efectiva dos meios de comunicação é hoje consensualmente aceite (Gilboa, 2005). O próprio Richard Nixon (1980: 116) confirma o poder dos media ao atribuir-lhes um papel determinante no desfecho da Guerra do Vietname: "A cobertura desonesta e dúbia da Guerra do Vietname não constituiu um dos mais belos momentos da comunicação social americana. Distorceu poderosamente a percepção pública, e isso reflectiu-se no Congresso".

O enquadramento legal doméstico também pode condicionar as decisões de política externa. A legislação nacional pode, em muitos casos, condicionar as opções disponíveis aos líderes. A Administração Clinton, por exemplo, viu-se limitada na sua perseguição a Bin Laden pela proibição consagrada na Ordem Executiva 12333 de Dezembro de 1981 e que impede as agências governamentais americanas de participar em assassinatos políticos (Woodward, 2005). Noutros Estados esta diversidade de condicionantes não é tão manifesta. No caso chinês, o Partido Comunista Chinês retém ainda um elevado controlo sobre o processo de política externa. Embora nos últimos anos se tenham verificado alterações significativas na participação de outros actores domésticos no processo de decisão política (Gilboy e Read, 2008), «O Partido mantém o seu direito de permanecer como o derradeiro actor político no país» (Lanteigne, 2009: 24). A abertura chinesa nas últimas décadas acabou por aumentar a capacidade reivindicativa de vários actores 
domésticos que tradicionalmente não tinham qualquer dinâmica política como são os casos da classe empresarial, das ONG, grupos de interesse organizados e think tanks (Lanteigne, 2009: 24).

A discrepância entre o número de factores domésticos que determinam e condicionam a política externa dos diferentes Estados é muitas vezes consequência de diferenças culturais. As culturas nacionais - conjunto unificado de ideias que são compartilhadas pelos membros de uma sociedade e que estabelecem um conjunto partilhado de premissas, valores, expectativas e predisposições entre os membros da nação como um todo - influenciam o processo de decisão de diversas formas (Vertzberger, 2002). Mais especificamente, a cultura actua sobre a forma como os indivíduos contextualizam e compreendem as diferentes situações, destacando determinados tipos de informações sobre outras, e as formas de lidar com elas. Vários estudos têm evidenciado como os factores culturais condicionam a política externa. Numa investigação recente, Yang, Geva e Chang demonstraram que os decisores americanos são mais propícios ao risco do que os decisores chineses. Os diferentes contextos culturais determinam que, perante a mesma escolha, os chineses têm expectativas de benefícios maiores do que os americanos (Mintz e DeRouen Jr., 2010). Desta forma, os vários estudos têm alegado que as diferenças culturais afectam tanto a escolha como o processo de decisão.

Todos estes factores contribuem para a complexidade do ambiente de decisão. Porém, é a dimensão psicológica que permite aos decisores compreender e avaliar os factores internacionais e domésticos, integrando-os no processo de decisão externa.

\section{Factores psicológicos}

Os factores psicológicos adquirem especial importância quando "as representações dos problemas são contestadas, quando os problemas não são rotineiros, quando há muito em jogo para os decisores e quando o ambiente oferece um grau suficientemente amplo de liberdade que permite um vasto leque de escolhas» (Stein, 2005). Porém, os factores psicológicos são determinantes em todas as situações. De acordo com Renshon e Renshon 
(2008: 511), «[a] enorme complexidade do mundo real, associada à nossa incapacidade para apreender e compreender todos os seus elementos, requer métodos de redução da complexidade». São os processos cognitivos dos indivíduos que permitem reduzir a complexidade do mundo político (Jervis, 1976). Mais concretamente, os processos cognitivos produzem determinadas crenças e construções psicológicas que possibilitam aos decisores impor ordem e sentido ao seu ambiente político.

Deste modo, uma abordagem dos factores psicológicos envolvidos na decisão de política externa procura conhecer «as estratégias cognitivas que os responsáveis políticos empregam para construir e manter as suas imagens simplificadas do ambiente» (Tetlock e McGuire Jr., 1999: 506). Contudo, existe uma soma infindável de factores cognitivos que influenciam os processos de decisão de política externa. Neste caso, somente analisamos os mais conhecidos e explorados na bibliografia temática. De forma a sintetizar a variedade de conceitos e métodos existentes nesta área temática, empregamos a classificação utilizada por Jerel Rosati (2001) para distinguir a forma como os factores cognitivos afectam a política internacional, designadamente através do conteúdo, organização e estrutura das crenças dos decisores; dos padrões comuns de percepção e erros de percepção; da rigidez e flexibilidade cognitiva; e do impacto na elaboração política.

O conhecimento do conteúdo das crenças é essencial, pois o que os decisores acreditam é determinante para informar as suas decisões. Existe uma profusão de abordagens cognitivas que permitem aferir os conteúdos das crenças dos decisores, desde as mais genéricas às mais particularizadas. Uma das abordagens mais utilizadas para identificar as imagens gerais dos decisores é através da análise dos seus "códigos operacionais». Estes compreendem um conjunto coerente de convicções sobre a natureza da vida política internacional (Alexander, 1969). As crenças subjacentes aos códigos operacionais são decompostas na sua dimensão "filosófica» (crenças que definem a situação) e «instrumental» (crenças que determinam o comportamento). Para poder desvendar os códigos operacionais dos decisores, Alexander propõe um conjunto de dez perguntas que têm de ser respondidas sobre as crenças filosóficas e instrumentais. A sua análise permite aos 
investigadores identificar a tendência ideológica e orientação de política externa geral dos decisores.

Os mapas cognitivos também são utilizados para aferir o conteúdo das crenças dos decisores. A ênfase dos mapas cognitivos é na determinação da forma como as crenças do decisor motivam determinados comportamentos. De forma a revelar a complexidade do processo de decisão, os mapas cognitivos evidenciam a relação causal entre as convicções pessoais e as opções políticas, nomeadamente através da aplicação de modelos matemáticos representados por esquemas ilustrados (Axelrod, 1976).

Outra forma de identificar o conteúdo das crenças dos decisores é através da análise das imagens que têm sobre o ambiente internacional. As imagens consistem em simplificações do mundo político e resultam da avaliação que os decisores fazem relativamente às capacidades, relação e cultura de outro Estado (Mintz e DeRouen Jr., 2010; Schafer, 1997). As imagens ajudam os decisores a enquadrar e perceber a informação complexa existente no ambiente político internacional, nomeadamente através da categorização dos diferentes eventos e actores. Desta forma, estas abordagens cognitivas diferenciadas possibilitam uma análise ampla das diversas crenças que os indivíduos têm sobre o ambiente político internacional, desde as mais genéricas às mais específicas.

A forma como o decisor organiza e estrutura as suas crenças é igualmente determinante para o processo de decisão de política externa. A sua compreensão facilita a análise da coerência do sistema de crenças dos responsáveis políticos. A questão central desta perspectiva assenta na consistência ou fragilidade do sistema de crenças e imagens dos políticos. A tese da consistência cognitiva defende que os indivíduos tendem a assimilar informação nova de forma a encaixá-la congruentemente nas suas crenças e imagens préexistentes (Jervis, 1976). Consequentemente, qualquer informação discordante é recusada durante o processo de decisão. O estudo de Holsti (2006) sobre o Secretário de Estado americano John Foster Dulles realça esta tendência para a manutenção da rigidez cognitiva. Dulles mantinha a sua imagem negativa dos soviéticos mesmo quando a informação que recebia contrastava essa ideia. O Secretário de Estado rejeitava as informações contrárias com base no argumento que os soviéticos estavam a aplicar estratagemas para iludir os americanos sobre os seus verdadeiros objectivos expansionistas. 
Desde a década de 1970 que se desenvolvem perspectivas que privilegiam processos cognitivos mais complexos. Em vez de inflexibilidade cognitiva, o decisor é encarado como um "avarento» cognitivo (cognitive miser) no sentido em que devido à sua limitada capacidade para processar informação ele é obrigado a recorrer a esquemas e atalhos mentais para simplificar a informação (Rosati, 2001). Desta forma, os esquemas encerram informação genérica sobre o mundo, pois são «estruturas cognitivas que representam conhecimento sobre um conceito ou tipo de estímulo, incluindo os seus atributos e as relações entre esses mesmos atributos»(Larson, 1994). Mais do que simples crenças, os esquemas incluem exemplos específicos e analogias derivados da experiência pessoal (Larson, 1994). Desta forma, as crenças pré-existentes ainda são consideradas importantes para interpretar informação nova, mas os sistemas de crenças são entendidos como mais fragmentados, com diferentes crenças ou esquemas invocados em diferentes situações para dar sentido à complexidade do ambiente político. Mediante este entendimento, a possibilidade dos decisores modificarem as suas crenças é mais facilmente abraçada.

Alguns estudos têm verificado que ambos os padrões são possíveis. Num estudo sobre as imagens que a Administração Truman tinha sobre a União Soviética, Larson testemunha que enquanto Acheson manteve uma imagem estável e coerente ao longo dos anos, outros elementos da Administração (por exemplo, Truman, Harriman, Brynes) demonstraram inconsistências em vários períodos (Rosati, 2001). Por sua vez, Rosati (1991) evidencia o mesmo padrão na Administração Carter. Todos os elementos responsáveis pela política externa revelaram alterar as suas imagens do sistema internacional ao longo dos anos, passando de uma visão mais optimista e cooperativa para uma mais negativa e hostil.

De acordo com Rosati (2001) três factores estão implícitos na definição das estruturas cognitivas e contribuem para a sua maior inflexibilidade ou fragmentação:

- O nível de conhecimento e experiência do decisor - a distinção entre decisores experientes e principiantes determina que quanto mais experiência e conhecimento efectivo um indivíduo tem, maior a coerência das suas imagens e crenças. Contrariamente, quanto menos 
experiência e conhecimento o indivíduo tem, maior a tendência para a inconsistência e fragmentação das crenças;

- O papel desempenhado pelo decisor - a função que cada indivíduo desempenha no processo de decisão também condiciona a sua estrutura cognitiva. No modelo apresentado por Steinbruner existem três formas comuns de pensar entre os decisores - 1) os burocratas que assentam as suas actividades em rotinas e na consistência processual; 2) os teóricos, que ocupam os lugares intermédios no processo de decisão e estão mais dispostos a considerações abstractas, embora revelando uma notável consistência ao longo do tempo; e 3) os descomprometidos, que ocupam os lugares cimeiros no processo de decisão e são alvo de uma vasta quantidade de informação, optando por soluções diferentes em situações análogas (Rosati, 2001);

- A situação e as expectativas mantidas pelo decisor em determinado momento - os decisores tendem a ser mais influenciados conforme preocupações imediatas que os ocupam. De acordo com Jervis (1976) as preocupações imediatas (evoked sets) dos decisores levam-nos a interpretar as informações recebidas de acordo com os assuntos que mais os consomem nesse momento. Assim, "para adivinhar as inferências que uma pessoa irá retirar de um determinado sinal necessitamos muitas vezes de saber quais os problemas que a preocupam e qual a informação que recebeu recentemente» (Jervis, 1976: 203).

A par com o conteúdo e estrutura cognitiva dos decisores é necessário analisar os padrões comuns de percepção e erros de percepção para compreender algumas das dinâmicas inerentes aos processos de decisão de política externa. Rosati (2001) identifica três padrões de percepção utilizados pelos decisores para organizarem e trazerem ordem à complexidade do ambiente político:

- Tendência para categorizar e estereotipar - para impor alguma ordem na quantidade de informação que adquirem do seu ambiente político, os indivíduos compartimentam e organizam a informação recebida. A simplificação envolvida neste processo leva normalmente à estere- 
otipagem dos eventos e actores. Neste processo há propensão para simplificar as situações de tal forma que se perdem muitos dos traços distintivos das mesmas, criando-se categorias antagónicas como nóseles, bons-maus, etc;

- Tendência para simplificar inferências causais - os indivíduos procuram sempre explicações para as diferentes ocorrências. Um erro de percepção comum é atribuir aos adversários maiores capacidades e responsabilidades do que efectivamente têm. Assim, assume-se que o comportamento dos Estados adversários é geralmente mais centralizado, melhor planeado e mais coordenado do que realmente é. Isto porque, como explica Jervis (1976: 319) «é uma manifestação do ímpeto para comprimir eventos complexos e não-relacionados num padrão coerente». Das diversas inferências causais associadas ao processo de decisão de política externa algumas revelam-se particularmente importantes (Rosati, 2001): tendência para sobrestimar ou subestimar as causas disposicionais e situacionais do comportamento; tendência para sobrestimar ou subestimar a própria importância; tendência para sobrestimar o planeamento e centralização das actividades de outros; tendência para ceder a pensamentos pessimistas ou demasiado optimistas; tendência para utilizar analogias históricas - na busca de soluções simples, os indivíduos têm propensão para utilizar as lições do passado para responder aos desafios do momento. Os eventos internacionais passados servem de repertório de opções à disposição dos decisores. Vertzberger (2002) esclarece que os decisores geralmente utilizam as analogias históricas para definir a situação, circunscrever funções, e determinar e justificar a estratégia.

A abordagem cognitiva também é útil para determinar a rigidez e flexibilidade cognitiva dos decisores de política externa. Segundo Rokeach as diferentes crenças dos indivíduos não têm todas a mesma importância (Rosati, 2001). Aliás, quanto mais central uma crença é para um indivíduo, mais resistente será à mudança. Se eventualmente ocorrer uma mudança numa crença central, maior será a implicação dessa transformação no restante sistema de crenças. Todavia, conforme foi exposto anteriormente, a teoria da consistência cognitiva e teoria dos esquemas diferem na probabilidade 
e na natureza das transformações das crenças. A primeira, subscrevendo a inflexibilidade cognitiva, ao salientar a interdependência das crenças assume que uma transformação a ocorrer repercutir-se-ia em todo o sistema de crenças (Jervis, 1976). Por sua vez, a teoria dos esquemas, apoiando-se nas teorias da cognição social, argumenta que as crenças são muito menos interdependentes, facilitando alterações de crenças singulares incrementadas ao longo do tempo. As implicações destas diferentes perspectivas para o processo de decisão são profundas. Em última instância, comprometem a capacidade dos mais variados decisores políticos (incluindo organizações) para aprender com as suas diversas experiências. Implicam, igualmente, a capacidade que os decisores possuem para se adaptar a novas situações e transformações no seu ambiente político (Rosati, 2001).

No que se refere ao impacto dos factores cognitivos na elaboração política, estes fazem-se sentir em duas etapas distintas: 1) na definição da agenda e 2) na formulação e decisão da política externa. No primeiro ponto, o estudo da definição das agendas tem ocupado um lugar periférico na análise de política externa (Rosati, 2001). Contudo, é de todo o interesse compreender como é que os factores cognitivos influenciam as percepções do ambiente de decisão dos decisores, pois «a forma como o problema é definido e representado é crucial à sua possível solução" (Sylvan, 1998: 3). Por sua vez, como anteriormente foi evidenciado, os factores cognitivos actuam no processo de decisão simplificando o processo, minimizando os custos psicológicos inerentes ao ambiente político. Mais especificamente, os processos cognitivos separam os valores e os objectivos, limitam a procura de informação, reduzem a consideração de alternativas, privilegiam a alternativa mais próxima dos objectivos escolhidos e constringem a capacidade de aprendizagem (Rosati, 2001).

\section{Propostas para melhorar o processo de decisão de politica externa}

As decisões de política externa serão sempre resultado de processos complexos e imperfeitos. Contudo, há formas de melhorar o desempenho das organizações, grupos e decisores de forma a reduzir a quantidade e 
dimensão das condicionantes. Neste sentido, vários modelos têm sido desenvolvidos que procuram melhorar a qualidade do processo de decisão, evitando algumas das tendências e vícios de forma acima referidos. No modelo desenvolvido por Alexander George (1980), este defende a necessidade de um sistema de advocacia múltipla (multiple advocacy), no qual são potenciados os conflitos e desacordos inerentes ao processo de decisão. O sistema compreende uma estrutura mista em que o poder executivo se conjuga com vários actores que representam perspectivas distintas. Desta forma, para garantir que se analisem as várias opções políticas, o líder promove a competição entre as diferentes organizações ou indivíduos de forma a evitar a omissão de alternativas. O modelo de advocacia múltipla impõe três condições: 1) os diferentes elementos devem exibir diversidade de perspectivas e deve haver uma distribuição equilibrada em termos de poder (influência), competência, informação, recursos analíticos e aptidões negociais ou de persuasão; 2) o poder executivo deve monitorizar e regular activamente o processo; 3) deve existir tempo suficiente para se debater e negociar as diferentes opções.

Por sua vez, o modelo do advogado do diabo (devil's advocate) é destinado a descrever o papel de um determinado indivíduo e não uma estrutura de decisão (como o modelo anterior). Na sua concepção teórica, o modelo implica que nas decisões de política externa mais importantes haja pelo menos um consultor sénior que tenha (ou tome) uma posição divergente e argumente em seu favor. O objectivo do advogado do diabo é contrariar a propensão excessiva para haver conformidade nos grupos, nomeadamente através de comportamentos que procuram consenso (George, 1980). Contudo, há vários obstáculos à sua aplicação efectiva. Logo à partida, pode não existir nenhum membro na estrutura de decisão que tenha uma opinião divergente. Embora se possa nomear um elemento para argumentar uma posição discordante, este pode ser encarado como somente desempenhando um papel, não evidenciando nenhuma convicção real a favor dessa perspectiva. O próprio advogado do diabo indicado pode também não estar totalmente comprometido com a abordagem dissidente e não desenvolver os esforços necessários para bloquear a posição maioritária ou até mesmo alterá-la. 
Yaacov Vertzberger (2002) propõe medidas mais vocacionadas para aumentar a capacidade técnica das organizações burocráticas. No seu entender deve haver mecanismos que evitem a politização das burocracias, permitindo a prossecução de propostas livres de caprichos políticos. Porém, nada garante que as avaliações e recomendações de política externa feitas pelos tecnocratas das burocracias estatais estejam livres de deficiências e não evidenciem perspectivas tendenciosas. Vertzberger insiste que é necessário estimular formas de pensamento criativas para evitar algumas das lacunas actuais, nomeadamente através da formação contínua dos burocratas e da monitorização dos processos de decisão. Essas propostas podem contribuir para de facto aperfeiçoar o processo de decisão. Contudo, acreditamos que a forma mais elementar para melhorar o processo de decisão passa pela consciencialização da sua existência e reconhecimento dos principais desafios que se lhe colocam.

\section{Conclusão}

Ao longo deste capítulo procurou-se demonstrar que a política externa é caracterizada por um elevado grau de complexidade. Os problemas que os decisores enfrentam são complicados e os processos de decisão envolvem dificuldades múltiplas. A própria definição de política externa não é consensual e a natureza fluida do ambiente político internacional contemporâneo impõe uma renovada reflexão sobre a sua conceptualização. Todavia, é possível identificar alguns modelos, dinâmicas e actores que ajudam a atenuar a complexidade e melhor compreender a política internacional. A formulação e decisão de política externa podem ser analisadas e compreendidas através de vários modelos que se focam em níveis de análise distintos. Ao tradicional modelo do actor racional, juntam-se-lhe os modelos das organizações burocráticas, dos pequenos grupos e dos líderes. Cada modelo encerra vantagens e inconvenientes na sua apreciação do processo de decisão de política externa. O processo de decisão é igualmente sujeito a enormes complexidades. Não só as decisões diferem no seu tipo e na sua forma, como o ambiente de decisão cria imperativos 
aos decisores que os obriga a decidir em condições que não são as mais adequadas. O ambiente político internacional também dificulta o processo, revelando-se opaco dada a multiplicidade de factores na identificação e avaliação da situação política. O processo de decisão de política externa é condicionado ainda por factores externos, domésticos e psicológicos. A maior parte destes factores são imperceptíveis ao olhar desatento. A análise de política externa centrada nos processos de decisão permite identificar e explicar muitos destes fenómenos. Acima de tudo, possibilita reconhecer esses factores e procurar, se não corrigi-los, evitar os seus efeitos perversos na formulação de política externa.

\section{Questões para análise}

Quais os pressupostos basilares dos estudos iniciais de análise de política externa e como é que se coadunam com a realidade da política internacional contemporânea?

Porque é que os modelos de análise de política externa adquiriram maior ênfase com o término da Guerra Fria?

Como é que o ambiente político internacional condiciona o processo de decisão de política externa?

Como é que os factores cognitivos influenciam a decisão de política externa?

Em que medida é que é possível corrigir algumas das deficiências do processo de decisão de política externa?

\section{Leituras recomendadas}

Allison, Graham e Zelikow, Philip (1999) Essence of Decision: Explaining the Cuban Missile Crisis. New York: Addison-Wesley Longman, Inc.

George, Alexander (1980) Presidential Decisionmaking in Foreign Policy: The Effective Use of Information and Advice. Boulder, Colorado: Westview Press.

Jervis, R. (1976) Perception and Misperception in International Politics. Princeton, New Jersey: Princeton University Press.

Mintz, Alex e DeRouen Jr., Karl (2010) Understanding Foreign Policy Decision 
Making. New York: Cambridge University Press.

Vertzberger, Yaacov (2002) The World in their Minds: Information Processing, Cognition and Perception in Foreign Policy Decisionmaking. Stanford, California: Stanford University Press.

\section{Bibliografia}

Allison, G. e Zelikow, P. (1999) Essence of Decision: Explaining the Cuban Missile Crisis. New York: Addison-Wesley Longman, Inc.

Axelrod, R. (1976) Structure of Decision: The Cognitive Maps of Political Elites. Princeton, New Jersey: Princeton University Press.

Breuning, M. (2007) Foreign Policy Analysis: A Comparative Introduction. New York: Palgrave Macmillan.

Campbell, D. (1993) Politics without Principle: Sovereignty, Ethics, and the Narratives of the Gulf War. Boulder: Lynne-Rienner.

Chollet, D. e Goldgeier, J. (2008) America between the Wars: From 11/9 to 9/11. The Misunderstood Years Between the Fall of the Berlin Wall and the Start of the War on Terror. New York: Public Affairs.

Doty, R. (1997) «Aporia: A Critical Examination of the Agent-Structure Problematique in International Relations Theory” European Journal of International Relations, 3: 365-392.

Doyle, M. (1983) «Kant, Liberal Legacies, and Foreign Affairs», Philosophy and Public Affairs, 12(3), 205-235.

Freedman, L. (2004) Deterrence. Cambridge: Polity Press.

Foot, R. (2006) "Chinese Strategies in a US-hegemonic Global Order: Accommodating and Hedging", International Affairs, 82(1), 77-94.

George, A. (1980) Presidential Decisionmaking in Foreign Policy: The Effective Use of Information and Advice. Boulder, Colorado: Westview Press.

George, A. (1969) «The 'Operational Code': A Neglected Approach to the Study of Political Leaders and Decision-Making, International Studies Quarterly, 13(2), 190-222.

Gilboa, E. (2005) «The CNN Effect: The Search for a Communication Theory of International Relations", Political Communications, 22(1), 27-44.

Gilboy, G. e Read, B. (2008) "Political and Social Reform in China: Alive and Walking», The Washington Quarterly, 31(3), 143-164.

Gray, C. (2007) War, Peace, and International Relations: An Introduction to Strategic History. New York: Routledge.

Gustavsson, J. (1999) «How Should We Study Foreign Policy Change?», Cooperation and Conflict, 34(1): 73-95.

Haas, P. (1992) «Introduction: Epistemic Communities and International Policy Coordination», International Organization, 46(1), 1-35.

Hagan, J. (2001) «Does Decision Making Matter? Systemic Assumptions vs. Historical Reality in International Relations Theory», International Studies Review, 3(2): 5-47. 
Hermann, C. (1990) "Changing Course: When Governments Choose to Redirect Foreign Policy», International Studies Quarterly, 34(1), 3-21.

Holsti, O. (2006) Making American Foreign Policy. New York: Routledge.

Hudson, V. (2008) "The History and Evolution of Foreign Policy Analysis», in Smith, S., Hadfield, A. e Dunne T. (org), Foreign Policy: Theories, Actors, Cases. Oxford: Oxford University Press, 11-30.

Hudson, V. e Vore, C. (1995) «Foreign Policy Analysis Yesterday, Today, and Tomorrow», Mershon International Studies Review, 39(2), 209-238.

Ikenberry, J. (2008) "The Rise of China and the Future of the West: Can the Liberal System Survive?», Foreign Affairs, 87(1), 23-37.

Jacobs, L e Page, B. (2005) «Who Influences Foreign Policy?», American Political Science Review, 99(1), 1-17.

Janis, I. (1971) "Groupthink», Psychology Today Magazine, 84-90.

Jervis, R. (1976) Perception and Misperception in International Politics. Princeton, New Jersey: Princeton University Press.

Jørgensen, K. E. (2006) "Theoretical perspectives on the role of values, images and principles in foreign policy", in Lucarelli, S. e Manners, I. (org), Values and Principles in European Union Foreign policy. London: Routledge, 42-58.

Keohane, R. e Nye, J. (2000) Power and Interdependence. $3^{\mathrm{a}}$ ed. New York: Longman.

Lanteigne, M. (2009) Chinese Foreign Policy: An Introduction. London: Routledge.

Larsen, H. (1997) Foreign Policy and Discourse Analysis: France, Britain and Europe. London: Routledge.

Larson, D. (1994) "The Role of Belief Systems and Schemas in Foreign Policy Decision-Making», Political Psychology, 15(1), 17-33.

Levy, J. (1981) "Alliance Formation and War Behavior: An Analysis of the Great Powers, 1495-1975", Journal of Conflict Resolution, 25(4), 581-613.

Lincoln, Abraham (1864) "Letter to Albert G. Hodges», Sumário da missiva. [http://showcase. netins.net/web/creative/lincoln/speeches/hodges.htm].

Mearsheimer, J. e Walt, S. (2008) The Israel Lobby and US Foreign Policy. New York: Farrar, Straus and Giroux.

Mintz, A. e DeRouen Jr., K. (2010) Understanding Foreign Policy Decision Making. New York: Cambridge University Press.

Neack, L. (2008) The New Foreign Policy: Power Seeking in a Globalized Era. New York: Rowman \& Littlefield Publishers, Inc.

Neack, L.; Hey, J. and Haney, P. (1995) "Generational Change in Foreign Policy Analysis», in Neack, L.; Hey, J. e Haney, P. (org), Foreign Policy Analysis: Continuity and Change in its Second Generation. Englewood Cliffs: Prentice Hall.

Nixon, Richard (1980) A Verdadeira Guerra. Lisboa: Portugália Editora.

Nye Jr., J. (2002) Compreender os Conflitos Internacionais: Uma Introdução à Teoria e à História. Lisboa: Gradiva Publicações, Lda.

Renshon, J. e Renshon, S. (2008) "The Theory and Practice of Foreign Policy Decision Making", Political Psychology, 29(4), 509-536.

Rosati, J. (2001) "The Power of Human Cognition in the Study of World Politics», International Studies Review, 2(3), 45-75. 
Rosati, J. (1994) «Cycles in Foreign Policy Restructuring: The Politics of Continuity and Change in US Foreign Policy", in Rosati, J; Hagan, J e Sampson III, M. (org), Foreign Policy Restructuring: How Governments Respond to Global Change. Columbia, South Carolina: University of South Carolina Press, 221-261.

Rosati, Jerel (1991) The Carter Administration's Quest for Global Community: Beliefs and Their Impact on Behavior. Columbia, South Carolina: University of South Carolina Press.

Rosenau, J. (1966) «Pre-theories and Theories of Foreign Policy», in Farrell, R. B. (org), Approaches to Comparative and International Politics. Evanston: Northwestern University Press, 27-92.

Rosenau, J. ed. (1969) Linkage Politics: Essays on the Convergence of the National and International Politics. New York: Free Press.

Saideman, S. e Ayres, R. W. (2007) «Pie Crust Promises and the Sources of Foreign Policy: The Limited Impact of Accession and the Priority of Domestic Constituencies", Foreign Policy Analysis, 3(3), 189-210.

Saunders, E. (2009) "Transformative Choices: Leaders and the Origin of Intervention Strategy», International Security, 34(2), 119-161.

Schafer, M. (1997) «Images and Policy Preferences», Political Psychology, 18(4), 813-829.

Simon, H. (1955) «A Behavioral Model of Rational Choice», The Quarterly Journal of Economics, 69(1), 99-118.

Sjöstedt, R. (2007) "The discursive origins of a doctrine: norms, identity, and securitization under Harry S. Truman and George W. Bush", Foreign Policy Analysis, 3(3): 233-254.

Snyder, R.; Bruck, H. e Sapin, B. (org) (2002) Foreign Policy Decision-Making (Revisited). New York: Palgrave-Macmillan.

Sprout, H. e Sprout, M. (1957) "Environmental Factors in the Study of International Politics», Journal of Conflict Resolution, 1(4), 309-328.

Sylvan, D. (1998) “Introduction», in Sylvan, D e Voss, J. (org), Problem Representation in Foreign Policy Decision Making. Cambridge: Cambridge University Press, 3-7.

Stein, J. (2005) «Psychological Explanations of International Conflict», in Carlsnaes, W; Risse, T. e Simmons, B. (org), Sage Handbook of International Relations. London: Sage, 292-308.

Tetlock, P. e McGuire Jr., C. (1999) "Cognitive Perspectives on Foreign Policy", in Ikenberry, G. J. (org), American Foreign Policy: Theoretical Essays. Massachusetts: Addison Wesley Longman, 504-521.

Vertzberger, Y. (2002) The World in their Minds: Information Processing, Cognition and Perception in Foreign Policy Decisionmaking. Stanford, California: Stanford University Press.

Wallace, M. (1979) "Arms Races and Escalation: Some New Evidence», Journal of Conflict Resolution, 23(3), 3-16.

Waltz, K. (1979) Theory of International Politics. Reading: Addison-Wesley.

Woodward, B. (2005) Bush at War. New York: Simon \& Schuster Paperbacks. 